\title{
Effect of Partially Replacing Corn Meal by Wet Date on Growth Performance in Nile Tilapia (Oreochromis niloticus) Fingerlings, Diets Supplemented with Digestarom ${ }^{\circledR}$
}

\author{
M. M. Gaber ${ }^{1}$, E. H. Labib² ${ }^{2}$ E. A. Omar², M. A. Zaki³ ${ }^{3}$ A. M. Nour ${ }^{3}$ \\ ${ }^{1}$ National Institute of Oceanography and Fisheries, Cairo, Egypt \\ ${ }^{2}$ Departments of Animal and Fish Production, Faculty of Agriculture, Alexandria University, Saba Basha, Egypt \\ ${ }^{3}$ Departments of Animal and Fish Production, Faculty of Agriculture, Alexandria University, El Shatby, Egypt \\ Email: gabermagdy@yahoo.com
}

Received January 2014

\section{Abstract}

A 3-month randomized factorial design $4 \times 2$ (four levels $0,15,30$, and $45 \%$ ) of wet Date (WD), two levels (0 and $0.03 \%$ ) of Digestarom ${ }^{\circledR}$ (D) and three replicates. The trial was conducted in twenty four glass aquaria. Ten fingerlings of Nile tilapia were placed in each aquarium with an average weight $15.40 \pm 0.3 \mathrm{~g}$ fish. Fish were fed twice daily (six days a week) at a rate of $3 \%$ of body weight. The results revealed that, mean final weight (g/fish), SGR (\%/day), feed conversion ratio, PPV and PER, were significantly ( $p \leq 0.05)$ affected by the levels of WD and level of $D$. And the best diet achieved which containing $30 \%$ WD supplemented with $0.03 \% \mathrm{D}$. From the above results and the economic information of these studies it can be concluded that, diet containing $30 \%$ of WD with $0.03 \% \mathrm{D}$ exhibited the highest net profit and would seem to be the most desirable level of WD and $D$ in the system studied.

\section{Keywords}

Nile Tilapia; Wet Date; Digestarom ${ }^{\circledR}$

\section{Introduction}

Annual production of wet date in Egypt about 1.1 million tons representing 16\% of total world production (FAO, 2004) and approximately $10-15 \%$ of this amount represents the total possible crop of wet date (110000-165000 tons annually). However, this amount was not all available, only those from manufactured date can be collected. Wet dates are easy to grind in an ordinary hammer mill (EL-Shazly et al., 1963). Therefore, they are first dried and powdered with grain grinder stone mill. Yousif, et al. (1996) reported that, the inclusion of the Wet date did not influence fish growth. Increasing body protein and decreasing body fat was observed of fish fed on diets

\footnotetext{
${ }^{*}$ Corresponding author.
}

How to cite this paper: Gaber, M. M. et al. (2014). Effect of Partially Replacing Corn Meal by Wet Date on Growth Performance in Nile Tilapia (Oreochromis niloticus) Fingerlings, Diets Supplemented with Digestarom . Journal of Geoscience and Environment Protection, 2, 60-67. http://dx.doi.org/10.4236/gep.2014.22010 
supplemented with date pits meal due to estrogenic action of date pits was hypothesized as direct cause of this phenomenon. Azaza et al. (2008) noted that, waste date meal could be substitute soybean meal up to $300 \mathrm{gkg}^{-1}$ without compromising growth of Nile tilapia. On the other hand El-Sayed et al. (2006) found that date pits based diets replaced up to $75 \%$ wheat bran resulted in reduced growth rates and feed utilization efficiency of Nile tilapia. And reported that, fungi degraded pits (DDP) could replace 300/kg dietary corn. While, Belal (2008) found that, growth performance of Nile tilapia fed sprouted date pits diets not differ from control diet. This study was carried out to determine the feasibility of using wet date as energy source for replacement corn meal in practical diets supplemented with $0.03 \%$ Digestarom ${ }^{\circledR}$ on Nile tilapia fingerlings.

\section{Material and Methods}

\subsection{Experimental Diets}

The wet dates were collected from waste date. The wet date were dried in oven dried at $60^{\circ} \mathrm{C}-80^{\circ} \mathrm{C}$ for $72 \mathrm{hr}$, then crushed in disc crusher and then powdered with grain grinding stone mill. The other materials were finely ground in a house blender and used in the formulation of eight experimental diets isonitrogenous (303 $\mathrm{gkg}^{-1}$ ) and isocaloric $\left(18.4 \mathrm{kjg}^{-1}\right)$. The experiment was designed in a factorial design $(4 \times 2)$. Eight tested diets were formulated to contain 0, 15, 30, and 45\% wet date instead of Yellow Corn meal, without or with 0.03 Digestarom $^{\circledR}$ as described in Table 1.

Each ingredient was thoroughly mixed with the other ingredients, vitamins, minerals mix and $0.03 \%$ Digestarom $^{\circledR}$ was then added to the diet 5-8 with continuous mixing. (Digestarom ${ }^{\circledR}(D)$ is a dried combination of natural attracting spices that stimulate digestibility). A few drops of soybean oil was added at the same time of mixing warm distilled water $\left(45^{\circ} \mathrm{C}\right)$ which was slowly added until the diets began to clump. Diets were processed by a mincer with die into $3 \mathrm{~mm}$ diameter, spaghetti-like strands, sun-dried and stored in air tight containers. The experimental fish were fed the test diets for a one week as adaptation period to adapt them to these test diets. After the adaptation period was completed, fish in each aquarium were reweighed, and their initial weights were recorded. Fish in each aquarium were fed twice daily (six days a week) at a rate of $3 \%$ of body weight for 90 days.

The experimental work of the present study was carried out at the Department of Animal and Fish Production, Faculty of Agriculture (El-Shatby); Alexandria University, Egypt.

\subsection{Culture Condition}

Nile tilapia (Oreochromis niloticus) fingerlings obtained from Berseek Fish Hatchery, El-Behera Governorate were used in the present study. Fish were placed randomly in twenty four glass aquaria with dimensions of 100 $\times 40 \times 30 \mathrm{~cm}$ and $100 \mathrm{l}$ capacity of water per aquarium, three replicates per treatment were used in this study. Each aquarium stocked with ten fingerlings of Nile tilapia with an average initial body weight of $15.40 \pm 0.3 \mathrm{~g}$ fish. Each aquarium was cleaned daily in order to prevent accumulation of fecal materials and reduce the growth of algae, and the same amount of fresh water was used to refill the aquaria. Water was partially changed once every three days using fresh water. Aeration was continuously provided using an air blower. The test diets were fed to triplicate aquaria two times daily at rate of $3 \%$ of body weight for 90 days.

\subsection{Preparation of Samples}

At the end of twelve weeks of growth study, fish per tank were collected for analysis. Fish were homogenized for whole body analysis and frozen at $-18^{\circ} \mathrm{C}$. The homogenized samples were oven dried at $60-80^{\circ} \mathrm{C}$ for $48 \mathrm{hrs}$. Proximate analyses of whole body, protein, lipid, and ash were performed according to standard AOAC (2000) methods and gross energy (Ballistic bomb calorimeter, Gallenhamp, England).

\subsection{Water Quality}

Water quality parameters (temperature, dissolved oxygen, $\mathrm{pH}$, ammonia, nitrate and nitrite) were monitored to ensure water quality remained well within limits recommended for Nile tilapia. Water temperature and dissolved oxygen were measured every other day using an YSI Model 58 oxygen meter (Yellow Springs Instruments, Yellow Springs, $\mathrm{OH})$. Ammonia and nitrite were measured at wkly intervals. Alkalinity was monitored twice weekly using the titration methods of Golterman et al. (1978) $\mathrm{pH}$ was monitored twice weekly using an elec- 
tronic $\mathrm{pH}$ meter (pH pen Fisher Scientific, Cincinnati, $\mathrm{OH}$ ). During the feeding trial, the water quality parameter averaged ( $\pm \mathrm{SD}$ ): water temperature $27.8 \pm 0.8^{\circ} \mathrm{C}$ dissolved oxygen $4.8 \pm 0.4 \mathrm{mgl}-1$; $\mathrm{pH} 7.4 \pm 0.6$; ammonia $0.01 \pm 0.04 \mathrm{mgl}-1$; nitrite $0.1 \pm 0.05 \mathrm{mgl}-1$; nitrate $1.5 \pm .2 \mathrm{mgl}-1$; alkalinity $181 \pm 46 \mathrm{mgl}-1$.

\subsection{Calculations and Statistical Analysis}

Calculations of growth parameters were conducted according Cho and Kaushik (1985). Data were analyzed by analysis of variance (ANOVA) using the SAS ANOVA procedure (Statistical analysis system 1933) Duncan's multiple range tests was used to compare differences among individual means. Treatment effects were considered significant at $\mathrm{p}<0.05$. All percentages and ratio were transformed to arcsine values prior to analysis (Zar, 1984).

\section{Results}

There were no significant differences in water quality parameter among the treatments during experimental period. Water quality parameters were within the acceptable range for Nile tilapia growth (Stickney, 1979).

\subsection{Feed Quality}

The amino acids as well as the nutrient contents of the diets are presented in Tables $\mathbf{1}$ and $\mathbf{2}$. The essential amino acid of the basal diets meets the requirements of Nile tilapia (Santiago and Lovell, 1988).

\subsection{Growth Performance}

The changes in mean body weight (g/fish) of Nile tilapia fed on eight tested diets containing $0,15,30$, and $45 \%$ WD instead of YC, without or with $0.03 \%$ Digestarom $^{\circledR}$ during the period of the experiment (3 months) are shown in Figure 1. In the beginning of the experiment, mean weight was not significantly different among the treatments $(\mathrm{p}>0.05)$. The overall averages \pm SD of Nile tilapia $15.4 \pm 0.5 \mathrm{~g} /$ fish for weight. At the end of the experiment, the mean weight (Figure 1) ranged between $49.6 \pm 3.5 \mathrm{~g}$ at the highest level wet date and $55.9 \pm 2.9 \mathrm{~g}$

Table 1. Composition of experimental diets fed to Nile tilapia fingerlings (g.100 g-1diet).

\begin{tabular}{|c|c|c|c|c|c|c|c|c|}
\hline \multirow{3}{*}{ Ingredients } & \multicolumn{8}{|c|}{ Diets } \\
\hline & \multicolumn{4}{|c|}{ Without Supplement D } & \multicolumn{4}{|c|}{ With D $0.03 \% \mathrm{D}$} \\
\hline & $1(0 \%)$ & $2(15 \%)$ & $3(30 \%)$ & $4(45 \%)$ & $5(0 \%)$ & $6(15 \%)$ & $7(30 \%)$ & $8(45 \%)$ \\
\hline Fish meal & 23.0 & 23.0 & 23.0 & 23.0 & 23.0 & 23.0 & 23.0 & 23.0 \\
\hline Soybean meal & 29.0 & 29.0 & 29.0 & 29.0 & 29.0 & 29.0 & 29.0 & 29.0 \\
\hline Yellow corn meal & 45.0 & 38.25 & 31.5 & 24.75 & 45.0 & 38.25 & 31.5 & 24.75 \\
\hline Wet date $(\mathrm{WD})^{1}$ & - & 6.75 & 13.5 & 20.25 & - & 6.75 & 13.5 & 20.25 \\
\hline Soybean oil & 2.0 & 2.0 & 2.0 & 2.0 & 2.0 & 2.0 & 2.0 & 2.0 \\
\hline Vita. \& $\min ^{2}$ & 1.0 & 1.0 & 1.0 & 1.0 & 1.0 & 1.0 & 1.0 & 1.0 \\
\hline Digestarom $^{\circledR 3}$ & -- & -- & -- & -- & 0.03 & 0.03 & 0.03 & 0.03 \\
\hline \multicolumn{9}{|c|}{ Proximate analyses (\%) } \\
\hline Moisture & 9.08 & 9.22 & 9.46 & 9.70 & 9.05 & 9.17 & 9.41 & 9.68 \\
\hline Crude protein & 30.49 & 30.43 & 30.43 & 30.40 & 30.49 & 30.47 & 30.43 & 30.40 \\
\hline Crude fat & 6.27 & 6.37 & 6.49 & 6.58 & 6.30 & 6.39 & 6.46 & 6.57 \\
\hline Ash & 7.71 & 8.25 & 8.8 & 9.33 & 7.75 & 8.26 & 8.81 & 9.32 \\
\hline Crude fiber & 4.89 & 4.95 & 5.03 & 5.09 & 4.91 & 4.96 & 5.04 & 5.08 \\
\hline $\mathrm{NFE}^{4}$ & 41.56 & 40.75 & 39.79 & 38.90 & 41.50 & 40.15 & 39.85 & 38.95 \\
\hline GE $\left(\mathrm{kjg}^{-1}\right)^{5}$ & 18.4 & 18.4 & 18.4 & 18.4 & 18.4 & 18.4 & 18.4 & 18.4 \\
\hline $\mathrm{P} / \mathrm{E}^{6}$ & 69.33 & 69.58 & 69.80 & 70.08 & 69.34 & 69.60 & 69.86 & 70.08 \\
\hline
\end{tabular}

${ }^{1}$ Wet Date meal, date waste seed and grinded to fine particles; ${ }^{2}$ Premix supplied according to Xie; Cui; Yang \& Liu (1997); ${ }^{3}$ Digestarom ${ }^{\circledR}$ (D) is a dried combination of natural attracting spices that stimulate digestibility; ${ }^{4} \mathrm{NFE}$ (Nitrogen free extract) $=100-(\%$ moisture $+\%$ C. protein $+\%$. fat $+\%$. fiber +ash); ${ }^{5}$ Gross energy (GE) = calculated as 5.621.64, 39.5 and 17.24 kjg-1 of protein, fat and carbohydrate respectively according to NRC, 1993); ${ }^{6} \mathrm{P} / \mathrm{E}$ ratio (protein to energy ratio) $=\mathrm{mg}$ protein $/ \mathrm{kj} \mathrm{GE}$. 
Table 2. Amino acid composition content of basal diet and amino acid requirements of Nile tilapia (g.100 g-1diet).

\begin{tabular}{ccc}
\hline Indispensable amino acid & Required $^{1}$ & Diet 1 (control) \\
\hline Arginine & 1.6 & 1.52 \\
Histidine & 0.65 & 0.97 \\
Isoleucine & 1.18 & 1.32 \\
Leucine & 1.29 & 1.81 \\
Lysine & 1.95 & 1.69 \\
Methionine & 1.02 & 0.88 \\
Phenylalanine & 1.43 & 1.22 \\
Threonine & 1.43 & 1.37 \\
Valine & 1.06 & 1.39 \\
\hline
\end{tabular}

${ }^{1}$ From Santiago \& Lovell (1988).

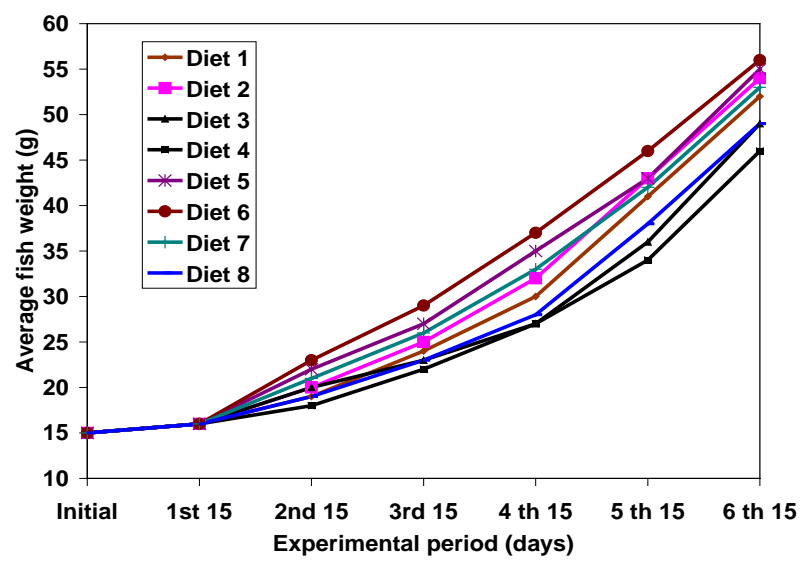

Figure 1. Effect of different levels of wet date diets supplemented with $0 \%$ and $0.03 \%$ Digestarom ${ }^{\circledR}$ on weight gains of Nile tilapia fingerlings.

at lowest level wet date. The mean weight was significantly affected by wet date, and D supplementation rate. The overall data of final individual weight and specific growth rate (SGR) for Nile tilapia reared at four levels wet date and D supplementation for a period of 3 months in aquarium are presented in Table 3 . It can be concluded from this table, mean final weight (g/fish), and SGR (\%/day) were significantly $(\mathrm{p}<0.05)$ affected and the best fish weight was obtained with the $30 \%$ level wet date and supplemented with $0.03 \% \mathrm{D}$.

The results of feed conversion ratio (FCR), protein productive value (PPV\%) and protein efficiency ratio (PER) are presented in Table 3. Feed conversion ratio and protein productive value, protein efficiency ratio were significantly $(\mathrm{p} \leq 0.05)$ affected by level wet date and exhibited the best results at the $30 \%$ level wet date and at supplemented with Digestarom ${ }^{\circledR}$ (D). Feed intake was significantly higher in Nile tilapia fed on 30\% WD at $0.03 \% \mathrm{D}$ than other WD levels. The feed conversion ratio (FCR) of Nile tilapia fed on $30 \% \mathrm{WD}$ at $0.03 \% \mathrm{D}$ was not significantly different ( $p>0.05$ ) when compared with control diet (Diets with $0 \%$ WD). Increasing dietary levels of WD from 30 to $45 \%$ caused decreasing feed intake and deterioration (FC). Protein efficiency ratio (PER), protein productive value (PPV) was significantly higher at 30\% WD and supplemented with $0.03 \% \mathrm{D}$. The lowest PER, PPV were observed at 45\% WD without and with D.

\subsection{Whole Body Composition}

The chemical compositions of whole body parameters of Nile tilapia fingerlings fed diets containing different levels of WD supplemented without and with $0.03 \%$ D are summarized in Table 4. Value of moisture, crude 
Table 3. Growth performance and nutrient utilization of Nile tilapia fed the experimental diets.

\begin{tabular}{|c|c|c|c|c|c|c|c|}
\hline \multirow{2}{*}{ Classification } & \multicolumn{2}{|c|}{ Average fish weight (g/fish) } & \multirow{2}{*}{$\mathrm{SGR}^{3}$} & \multirow{2}{*}{ FI (g/fish) ${ }^{4}$} & \multirow{2}{*}{$\mathrm{FCR}^{5}$} & \multirow{2}{*}{$\mathrm{PER}^{6}$} & \multirow{2}{*}{$\mathrm{PPV}^{7}$} \\
\hline & ${ }^{1} \mathrm{IBW}$ & ${ }^{2} \mathrm{FBW}$ & & & & & \\
\hline \multicolumn{8}{|l|}{ Wet date levels } \\
\hline $0 \%$ & $10.54 \pm 0.1$ & $42.19 \pm 5.6^{\mathrm{d}}$ & $1.65 \pm 0.2^{\mathrm{d}}$ & $45.4 \pm 1.7^{\mathrm{c}}$ & $1.47 \pm 0.2^{\mathrm{C}}$ & $2.3 \pm 0.3^{\mathrm{d}}$ & $34.0 \pm 4.7^{\mathrm{c}}$ \\
\hline $15 \%$ & $10.58 \pm 0.1$ & $45.94 \pm 2.9^{c}$ & $1.75 \pm 0.1^{\mathrm{c}}$ & $49.3 \pm 1.4^{\mathrm{b}}$ & $1.40 \pm 0.1^{\mathrm{b}}$ & $2.40 \pm 0.1^{\mathrm{c}}$ & $35.8 \pm 2.1^{\mathrm{c}}$ \\
\hline $30 \%$ & $10.51 \pm 0.1$ & $55.06 \pm 4.3^{\mathrm{a}}$ & $1.97 \pm 0.1^{\mathrm{a}}$ & $50.2 \pm 0.4^{\mathrm{b}}$ & $1.20 \pm 0.2^{\mathrm{a}}$ & $2.90 \pm 0.4^{\mathrm{a}}$ & $46.3 \pm 6.0^{\mathrm{a}}$ \\
\hline $45 \%$ & $10.59 \pm 0.1$ & $52.30 \pm 3.2^{\mathrm{b}}$ & $1.90 \pm 0.1^{\mathrm{b}}$ & $51.4 \pm 1.0^{\mathrm{a}}$ & $1.20 \pm 0.1^{\mathrm{a}}$ & $2.70 \pm 0.2^{\mathrm{b}}$ & $41.1 \pm 0.1^{\mathrm{b}}$ \\
\hline \multicolumn{8}{|l|}{ Digestarom $^{\circledR}$} \\
\hline $0 \%$ & $10.50 \pm 0.1$ & $45.25 \pm 5.8^{\mathrm{b}}$ & $1.73 \pm 0.2^{\mathrm{b}}$ & $48.2 \pm 2.8^{b}$ & $1.43 \pm 0.2^{\mathrm{b}}$ & $2.2 \pm 0.2^{\mathrm{b}}$ & $35.8 \pm 6.6^{\mathrm{b}}$ \\
\hline $0.03 \%$ & $10.61 \pm 0.1$ & $52.50 \pm 5.0^{\mathrm{a}}$ & $1.90 \pm 0.1^{\mathrm{a}}$ & $49.9 \pm 2.0^{\mathrm{a}}$ & $1.20 \pm 0.3^{\mathrm{a}}$ & $2.8 \pm 0.3^{\mathrm{a}}$ & $42.8 \pm 5.9^{\mathrm{a}}$ \\
\hline WD $\times$ D & N.S & $* *$ & $* *$ & $* *$ & $* *$ & $* *$ & $* *$ \\
\hline
\end{tabular}

Values are mean \pm standard deviation. Values in the same row with same superscripts are not significantly different (p $\geq 0.05) .{ }^{1}$ IBW $=$ initial body weight. ${ }^{2} \mathrm{FBW}=$ final body weight. ${ }^{3} \mathrm{SGR}$, specific growth rate $=($ Ln FBW-Ln IBW $) / 90 \times 100 .{ }^{4} \mathrm{FI}=$ feed intake ${ }^{5} \mathrm{FCR}$, feed conversion ratio $=$ dry feed fed/ body weight gain. ${ }^{6} \mathrm{PER}$, protein efficiency ratio = final body weight gain/protein intake X100. ${ }^{7} \mathrm{PPV} \%$, protein productive value = protein gained in fish body (g)/ protein fed (g) X100.

Table 4. Whole body composition (\% wet weight basis) of fish at the end of the experiment.

\begin{tabular}{|c|c|c|c|c|c|}
\hline Classification & Moisture & Crude protein & Ether extract & Ash & Energy $(\mathrm{Kj} / 100 \mathrm{~g})$ \\
\hline \multicolumn{6}{|c|}{ Wet date levels (WD) } \\
\hline $0 \%$ & $75.0 \pm 0.8^{\mathrm{a}}$ & $14.5 \pm 0.3^{\mathrm{b}}$ & $5.4 \pm 0.2^{\mathrm{b}}$ & $5.2 \pm 0.2^{\mathrm{b}}$ & \multirow{4}{*}{$\begin{array}{l}592.0 \pm 26.9^{\mathrm{ab}} \\
587.9 \pm 17.6^{\mathrm{c}} \\
599.2 \pm 11.1^{\mathrm{a}} \\
601.8 \pm 03.7^{\mathrm{a}}\end{array}$} \\
\hline $15 \%$ & $74.7 \pm 0.2^{\mathrm{ab}}$ & $14.7 \pm 0.2^{\mathrm{bc}}$ & $5.5 \pm 0.1^{\mathrm{b}}$ & $5.2 \pm 0.1^{\mathrm{b}}$ & \\
\hline $30 \%$ & $73.9 \pm 0.2^{\mathrm{bc}}$ & $15.5 \pm 0.1^{\mathrm{a}}$ & $5.8 \pm 0.1^{\mathrm{a}}$ & $4.9 \pm 0.1^{\mathrm{c}}$ & \\
\hline $45 \%$ & $74.5 \pm 0.2^{\mathrm{b}}$ & $14.8 \pm 0.2^{\mathrm{b}}$ & $5.4 \pm 0.1^{\mathrm{b}}$ & $5.4 \pm 0.1^{\mathrm{a}}$ & \\
\hline Digestarom $^{\circledR}$ (D) & NS & NS & NS & & \\
\hline $0 \%$ & $74.5 \pm 0.5$ & $14.8 \pm 0.4$ & $5.5 \pm 0.2$ & $5.2 \pm 0.2^{\mathrm{a}}$ & $596.8 \pm 11.2$ \\
\hline $0.03 \%$ & $74.5 \pm 0.8$ & $14.9 \pm 0.4$ & $5.6 \pm 0.2$ & $5.1 \pm 0.2^{b}$ & $593.7 \pm 21.6$ \\
\hline WD $x$ D & NS & NS & NS & $* *$ & $* *$ \\
\hline
\end{tabular}

Values are mean \pm standard deviation. Values in the same row with same superscripts are not significantly different ( $\mathrm{p} \geq 0.05$ ).

protein $(\mathrm{CP} \%)$, ether extract $(\mathrm{EE} \%)$ and ash content were highly significantly $(\mathrm{p}<0.05)$ different between all fish groups. However, energy contents significantly not $(\mathrm{p}>0.05)$ different among all fish groups. Incorporation WD at $30 \%$ replacement level only did significantly increase protein content.

\section{Discussion}

Approximately $30 \%$ of yellow corn meal (CM) energy could be replaced by WD, and result in growth rates in Nile tilapia higher than a CM-based diet. This is the first time to our knowledge that wet date meal has been demonstrated to be effective in replacing CM in fish diets. Based on feed intake the palatability of control diet and diets 2, 3, 5, 6 and 7 appeared to be better than the two diets 4 and 8 (Table 3 and Figure 1). Feed intake was significantly higher $(\mathrm{P}<0.05)$ in Nile tilapia fed diets containing $30 \%$ WD without and with $0.03 \% \mathrm{D}$. The feed conversion ratio (FCR) of Nile tilapia fed WD at 30\% inclusion levels was significantly different $(\mathrm{P}>0.05)$, compared with those fed other levels of WD. Increasing dietary WD levels from 30 to $45 \%$ caused significant deterioration in FCR $(\mathrm{P}<0.05)$. On the other hand, El-Sayed et al. (2006) noted that increasing dietary DP levels from 25 to $100 \%$ did not cause any further deterioration in FCR $(P>0.05)$. There were significant differences in weight gain and feed conversion (FCR) was significantly greater with diets $30 \% \mathrm{WD}$ at $0.03 \% \mathrm{D}$ than with the other diets. Diet 3 contained 30\% WD and represented the highest level of substitution, which was significantly different from the other diets (Table 3). These results are in agreement with the results of El-Sayed et al. (2006) and Yousif et al. (1996). While Osman et al. (2001) found that growth performance values were significantly $(\mathrm{P}<0.05)$ higher in Nile tilapia fed diet which containing $50 \%$ date pits treated with $\mathrm{H}_{2} \mathrm{SO}_{4}$ and $\mathrm{NaOH}$, whereas fish fed diet containing $50 \%$ untreated date pits gave the lowest values $(\mathrm{P}>0.05)$, in our experiment. 
Also, Belal (2008) found that growth performance of Nile tilapia fed diet containing of fungi Trichoderma reesei-degraded date pits DDP could replace $300 \mathrm{~g} \mathrm{~kg}^{-1}$ of dietary corn with better growth results, when compared with those fish fed the other diets.

In the present experiment, the lowest final fish weight was obtained by fish fed on diets containing 45\% WD replacing CM, without and with $0.03 \%$ D. similar results have been reported by Yousif et al. (1996), who found that blue tilapia (Oreochromis aureus) fed date pits as carbohydrate source without growth enhancing supplement had significantly poor performance. The poor performance of tilapia fed WD may have been due to their high contents of simple sugars (Yousif et al., 1996), whereas tilapia is known to utilize complex sugars more efficiently than simple sugars. In support, Shiau and Lin (1993) studied the effects of starch or fructose on the growth and feed efficiency of (Oreochromis. niloticus $x$ Oreochromis aureus) hybrids. They found that starch was better utilized than glucose. This result is also applied to specific growth rate (SGR\%). The results showed that diets containing $30 \%$ WD without or with $0.03 \% \mathrm{D}$ as feed additives was significantly different from control diets (1) in its effect on fish performances. The present results are in agreement with the finding of Belal and Al-Owafeir (2009) who found that growth performance, including SGR\% of Nile tilapia fed the control diet are similar to fish fed date pits fed at 15 and 30 levels. Similar results have been reported for probiotic use in diets for tilapia fingerling by Khattab et al. (2004); Salem (2008); Eid and Mohamed (2008); Mohamed et al. (2007), El-Dakar et al. (2007) and Carnevali et al. (2006).

Increasing dietary levels from 30 to $45 \%$ in the experimental diets with other additives increased significantly ( $\mathrm{P}<0.05$ ), protein efficiency ratio (PER), protein productive value (PPV\%) and energy utilization (EU\%) about control diet (2, 3, 4 and 5 vs. diet 1). Similar results have been reported by El-Sayed et al. (2006) who noted that PER, PPV\% and EU\% were significantly affected $(\mathrm{P}<0.05)$ by increasing date pits levels in Nile tilapia diets. Also significant $(\mathrm{P}<0.05)$ improvement was observed with $\mathrm{D}$ addition in FCR, PER and PPV within each replacement category. Protein efficiency ratio (PER) and protein productive value (PPV\%) were significantly higher on the replacement rate was 30\% WD and $0.03 \%$ D The lowest protein productive value (PPV\%) (30.7\%) was observed with diet (1) as opposining the high inclusion levels of Osman et al. (2001). The same trend was obtained with the Energy utilization (EU\%). However, these results are in agreement with the results of Mehrim, (2001); Diab et al. (2002); Khattab et al. (2004); Mohamed et al. (2007) and Eid and Mohamed (2008.), for tilapia. The present results confirm those obtained by Azaza et al. (2008) in their work on waste date meal fed to Nile tilapia and Abd El-Maksoud et al. (1999) on tilapia fed diets supplemented with Marjoram leaves.

Calculations of economical efficiency of the tested diets based on cost one kg gain in weight of Nile tilapia in comparison with the control group are shown in Table 5. Net profit were gradually increased with the increasing levels of WD and with addition of the D and reached the highest for the diet 3 and 7. At the level of WD replacement (30\%) with $0.03 \% \mathrm{D}$, it was found that Nile tilapia could be produced cheaper than fish fed on the

Table 5. Economic information for Nile tilapia.

\begin{tabular}{|c|c|c|c|c|c|c|c|c|}
\hline \multirow{3}{*}{ Items } & \multicolumn{8}{|c|}{ Diets } \\
\hline & \multicolumn{4}{|c|}{ Without supplement D } & \multicolumn{4}{|c|}{ With supplement D } \\
\hline & $1(0 \%)$ & $2(15 \%)$ & $3(30 \%)$ & $4(45 \%)$ & $5(0 \%)$ & $6(15 \%)$ & $7(30 \%)$ & $8(45 \%)$ \\
\hline Food cost kg diet (LE) & 2.9 & 2.7 & 2.8 & 2.7 & 2.9 & 2.8 & 2.8 & 2.7 \\
\hline No. fish stocked/m³ & 100 & 100 & 100 & 100 & 100 & 100 & 100 & 100 \\
\hline No fish harvested $\mathrm{m}^{3}$ & 100 & 100 & 100 & 100 & 100 & 100 & 100 & 100 \\
\hline Harvested (kgm $\left.{ }^{-1}\right)$ & 3.7 & 4.3 & 5.1 & 4.9 & 4.7 & 4.9 & 5.9 & 5.5 \\
\hline Food used(kg/m²) & 4.4 & 4.8 & 5.1 & 5.1 & 4.7 & 5.6 & 4.9 & 5.2 \\
\hline Fingerling cost $(\mathrm{LE})^{1}$ & 18.3 & 18.2 & 18.1 & 18.0 & 18.5 & 17.4 & 17.0 & 17.5 \\
\hline Food cost ${ }^{2}$ & 12.8 & 13.0 & 14.3 & 13.8 & 13.6 & 15.7 & 13.7 & 14.0 \\
\hline Total cost $(\mathrm{LE})$ & 31.1 & 31.2 & 32.4 & 31.8 & 32.1 & 33.1 & 30.7 & 31.5 \\
\hline Value of harvest (8.6 LE. $\mathrm{kg}^{-1}$ ) & 31.8 & 37.0 & 43.9 & 42.1 & 40.4 & 42.1 & 50.7 & 47.3 \\
\hline Net profit (LE) & 0.82 & 6.2 & 11.5 & 10.3 & 8.3 & 9.0 & 20.8 & 16.8 \\
\hline
\end{tabular}

${ }^{1} \mathrm{LE}=$ Lever Egyptian, one Dollar equal 6.12 LE; ${ }^{2}$ Feed cost of $1 \mathrm{~kg}$ ingredients used were 6 LE for fish meal, 23.9 LE for soybean meal, $1.75 \mathrm{LE}$ yellow corn meal, and $0.5 \mathrm{LE}$ date stone, $12 \mathrm{LE}$ for Digestarom ${ }^{\circledR}$, $6.5 \mathrm{LE}$ for soybean oil, $5.0 \mathrm{LE}$ vitamin and minerals, ingredient price at start of 2012. 
control diet. These results may indicate that the costs of one kg of diet declined by the incorporation of non conventional energy sources supplemented with $0.03 \% \mathrm{D}$ due to its low price and this is in agreement with El-Sayed et al., (2006) and from the previous results, it could be concluded that the diet containing 30\% WD with $0.03 \%$ Digestarom $^{\circledR}$ as dietary energy sources in formulation of Nile tilapia diets instead of $30 \%$ yellow corn meal have positive improvement effects on Nile tilapia performance. From feed utilization data and from the economical point of view the diet contained $30 \% \mathrm{WD}$ and supplemented with $0.03 \% \mathrm{D}$ could be recommended as feed for Nile tilapia fingerlings.

\section{References}

Abd El-Maksoud, A. M. S., Abouul-Fotouh, G. E., Allam, S. M., \& Abou Zied, R. M. (1999). Effect of Marjoram Leaves (Majorana hortensis) as a Feed Additive on the Performance of Nile Tilapia (Oreochromis niloticus) Fingerlings. Egyptian Journal of Nutrition and Feeds, 1, 39-47.

AOAC (2000). Association of Official Analytical Chemists, Official Methods of Analysis (17th ed.) Washington DC.

Azaza, M. S., Mensi, F., Kammoun, W., Abd Elouaheb, A., Brini, B., \& Kraiem, M. (2008). Nutritional Evaluation of Waste Date Fruit as Partial Substitute for Soybean Meal in Practical Diets of Juvenile Nile Tilapia, (Oreochromis niloticus). Aquaculture Nutrition Published Online: 2 June 2008, Journal Compilation (c) 2009 Blackwell Publishing.

Belal, I. E. H., \& Al-Owafeir, M. A. (2009). Incorporating Date Pits (Phoenix dactylifera) and Their Sprouts in Semi-Purified Diets for Nile Tilapia (Oreochromis niloticus L.). Journal of the World Aquaculture Society, 35, 452-459. http://dx.doi.org/10.1111/j.1749-7345.2004.tb00110.x

Belal, I. E. H. (2008). Evaluating Fungi-Degraded Date Pits as a Feed Ingredient for Nile Tilapia (Oreochromis niloticus L). Aquaculture Nutrition, 14, 445-452. http://dx.doi.org/10.1111/j.1365-2095.2007.00548.x

Carnevali, O., De Vivo, L., Sulpizio, R., Gioacchin, G., Olivotto, I., Silvi, S., \& Cresci, A. (2006). Growth Improvement by Probiotic European Sea Bass Juveniles (Dicentrarchus labrax, L.), with Particular Attention to IGF-1, Myostatin and Cortisol Gene Expression. Aquaculture, 258, 430-438. http://dx.doi.org/10.1016/j.aquaculture.2006.04.025

Cho, C. Y., \& Kaushik, S. J. (1985). Effect of Protein Intake on Metabolizable and Net Energy Values of Fish Diets. In: C. B. Cowey, A. M. Mackie, \& J. G. Bell (Eds.), Nutrition and Feeding in Fish (pp. 95-117). London: Academic Press.

Diab, A. S., EL-Nagar, O. G., \& Abd-El-Hady, M. Y. (2002). Evaluation of Nigella sativa L. (Black Seeds; Baraka), Allium sativum (Garlic) \& Biogen as a Feed Additives on Growth Performance of (Oreochromis niloticus) Fingerlings. Vetrenary Medical Journal, Suez Canal University, 2, 745-753.

Eid, A., \& Mohamed, K. A. (2008). Effect of Using Probiotic as Growth Promoters in Commercial Diets for Monosex Nile Tilapia (Oreochromis niloticus) Fingerlings. 8th International Symposium on Tilapia in Egypt.

El-Dakar, A. Y., Shalaby, S. M., \& Saoud, I. P. (2007). Assessing the Use of Dietary Probiotic/Prebiotic as Enhancer of Spine Foot Rabbit Fish (Singanus rivulatus) Survival and Growth. Aquaculture Nutrition, 13, 407-412. http://dx.doi.org/10.1111/j.1365-2095.2007.00491.x

El-Sayed, A. F. M., Hamza, W. R., \& Al-Darmaki, M. (2006). Evaluation of Date Pits as a Feed Ingredient for Juvenile and Adult Nile tilapia (Oreochromis niloticus) Reared in a Recirculating System. Proceeding of 7th International Symposium on Tilapia aquaculture.

El-Shazly, K., Ibrahim, I., \& Karam, H. (1963). Nutritional Value of Date Seeds for Sheep. Journal of Animal Science, 22, 894-897.

FAO (Food and Agriculture Organization of the United Nations) (2004). Fishery Statistics 2002. Rome: Capture Production, FAO.

Golterman, H. L., Clymo R. S., \& Ohnstad, M. A. M. (1978). Methods of Physical and Chemical Analysis of Fresh Waters (214 p). Oxford: Blackwell Scientific Publications.

Khattab, Y. A. E., Shalaby, A. M. E., Saffa, M. S., El-Marakby, H., \& Rizl Alla, E. H. (2004). The Physiological Changes and Growth Performance of the Nile Tilapia (O. niloticus) after Feeding with Biogen ${ }^{\circledR}$ as Growth Promoter. Egypt Journal of Aquatic Biology and Fisheries, 8, 145-158.

Mehrim, A. I. M. (2001). Effect of Some Chemical Pollutants on Growth Performance, Feed and Nutrient Utilization of Nile Tilapia (O. niloticus) (215 p). M.Sc. Thesis, Saba Basha: Alexandria University.

Mohamed, K. A., Abdel Fattah, B., \& Eid, A. M. S. (2007). Evaluation of Using Some Feed Additives on Growth Performance and Feed Utilization of Monosex Nile Tilapia (O. niloticus) Fingerlings. Agricultural Research Journal, Suez Canal University, 7, 49-54.

NRC (1993). Nutrient Requirements of Warm Water Fishes and Shellfishes. Washington DC: National Academy Press.

Osman, M. F., Alhadrami, G. A., \& Ben Zayed, A. A. (2001). Sulfuric Acid Treated Date Pits as a Dietary Ingredient in Nile Tilapia (Oreochromis niloticus) Diets. Egyptian Journal of Nutrition and Feeds, 4, 753-754. 
Salem, M. E. M. (2008). Studies on Some Medicinal Plants as Mycotoxins in Fish Diets. M.Sc. Department of Animal Production, Thesis Submitted to the Faculty of Agriculture University Kafr Elsheikh University.

Santiago, C. B., \& Lovell, R. T. (1988). Amino Acid Requirements for Growth of Nile Tilapia. Journal of Nutrition, 188, 1540-1546.

Shiau, S. Y., \& Lin, S. E. (1993). Effect of Supplemental Dietary Chromium and Vanadium on the Utilization of Different Carohydrates in Tilapia Oreochromis niloticus $\times$ Oreochromis aureus. Aquaculture, 110, 321-330. http://dx.doi.org/10.1016/0044-8486(93)90379-D

Statistical Analysis System (1993). SAS/STAT User's Guide Release 6.03 Edition. Cary, North Carolina, USA: SAS Institute Inc.

Stickney, R. R. (1979). Principles of Warm Water Aquaculture. New York: Wiley International Science.

Xie, S., Cui, Y., Yang, Y., \& Liu, J. (1997). Energy Budget of Nile Tilapia, Oreochromis niloticus in Relation to Ration Size. Aquaculture, 154, 57-68. http://dx.doi.org/10.1016/S0044-8486(97)00039-2

Yousif, O. M., Osman, M. F., \& Alhadrami, G. A. (1996). Evaluation of Date and Date Pits as Dietary Ingredients in Tilapia (Oreochromis aureus) Diets Differing in Protein Sources. Bioresearch Technology, 57, 81-85. http://dx.doi.org/10.1016/0960-8524(96)00054-5

Zar, J. H. (1986). Biostatistician Analysis. New Jersey, USA: Prentice Hall, Englewood Cliffs. 